\title{
Attomole per Liter
}

National Cancer Institute

\section{Source}

National Cancer Institute. Attomole per Liter. NCI Thesaurus. Code C68888.

A unit of concentration (molarity unit) equal to one quintillionth of a mole (10E-18 mole)

of solute in one liter of solution. 